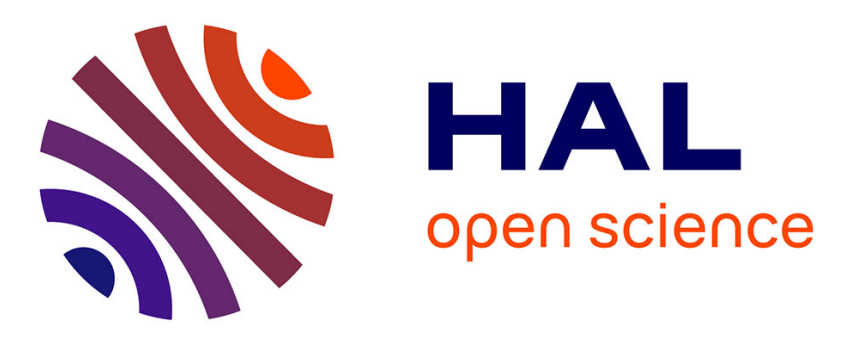

\title{
Synthesis of stereochemical probes for new fluorogenic assays for yeast transketolase variants.
}

Aurélie Sevestre, Franck Charmantray, Virgil Hélaine, Angelika Lasikova, Laurence Hecquet

\section{- To cite this version:}

Aurélie Sevestre, Franck Charmantray, Virgil Hélaine, Angelika Lasikova, Laurence Hecquet. Synthesis of stereochemical probes for new fluorogenic assays for yeast transketolase variants.. Tetrahedron, 2006, 62, pp.3969-3976. 10.1016/j.tet.2006.02.033 . hal-00022356

\section{HAL Id: hal-00022356 https://hal.science/hal-00022356}

Submitted on 26 Feb 2007

HAL is a multi-disciplinary open access archive for the deposit and dissemination of scientific research documents, whether they are published or not. The documents may come from teaching and research institutions in France or abroad, or from public or private research centers.
L'archive ouverte pluridisciplinaire HAL, est destinée au dépôt et à la diffusion de documents scientifiques de niveau recherche, publiés ou non, émanant des établissements d'enseignement et de recherche français ou étrangers, des laboratoires publics ou privés. 


\title{
Synthesis of stereochemical probes for new fluorogenic assays for yeast transketolase variants
}

\author{
Aurélie Sevestre, Franck Charmantray, Virgil Hélaine, \\ Angelika Lásiková and Laurence Hecquet* \\ Laboratoire de Synthèse et Etude de Systèmes à Intérêt Biologique, UMR CNRS 6504, Université Blaise Pascal, \\ 63177 Aubière Cedex, France
}

Received 16 November 2005; revised 12 January 2006; accepted 13 February 2006

Available online 9 March 2006

\begin{abstract}
For the screening of yeast transketolase (TK) variants with improved or new properties acquired by random mutagenesis, we report on the stereoselective synthesis of fluorogenic substrates as probes for meas uring TK activity. Compound 1 ( 7 - $\left(2^{\prime}, 3^{\prime}, 5^{\prime}\right.$-trihydroxy- $4^{\prime}$ oxo-pentyl)oxycoumarine), prepared as previously described, [Tetrahedron Lett. 2003, 44, 827-830] enabled us to evaluate wild type TK velocity in a simple, specific and reproducible way. To select TK mutants able to produce D-threo aldoses, we prepared compound 2 (dihydroxy-4-O-( $2^{\prime}$-oxo-benzopyran- $7^{\prime}$-yl-D-threose) from dimethyl tartrate. Starting from D-ribose, we successfully obtained compound 3 ( $7^{\prime}$-(2,3,5-trihydroxy-4-oxo-pentyl)oxycoumarine) as a probe for TK mutants able to produce L-erythro ketoses.

(C) 2006 Elsevier Ltd. All rights reserved.
\end{abstract}

\section{Introduction}

The discovery of new biocatalysts that mediate selective transformations is a growing field of research in organic chemistry. Diversity is either generated artificially by random mutagenesis from the gene that encodes an existing enzyme or collected directly from a natural reservoir. ${ }^{1}$ Such libraries must be screened to identify suitable enzymes with desired properties. Recently, new sensitive detection methods for the evaluation of large numbers of catalysts have been reported. Efficient high throughput screening assays have been achieved using solid phase bound tests related to immunoassays ${ }^{2}$ and a variety of spectroscopic methods, such as IR thermography ${ }^{3}$ or mass spectrometry. ${ }^{4}$ One of the most popular methods consists in using chromogenic or fluorogenic substrates as product formation sensors. ${ }^{5}$ In this area, Reymond developed a simple stereospecific assay consisting of a fluorescence release based on the secondary release of umbelliferone by $\beta$-elimination catalysed by bovine serum albumin (BSA) from a primary or secondary carbonyl reaction product. The prototypical example of this technique was an enantioselective assay for alcohol dehydrogenase. ${ }^{6}$ This approach was extended to the use of acylases, lipases, epoxide hydrolases, phophatases, ${ }^{7}$ aldolase catalytic antibodies ${ }^{8}$ and more recently for the transaldolase ${ }^{9}$ enzyme catalysing $\mathrm{C}-\mathrm{C}$ bond formation. In the latter case, the assay was based on microscopic reversibility, assuming that if transaldolase was able to cleave a $\mathrm{C}-\mathrm{C}$ bond by retroaldolisation, it would be able to catalyse its formation by aldolisation. Our interest in this assay stemmed from our ongoing investigation of TK enzyme catalysing a stereocontrolled $\mathrm{C}-\mathrm{C}$ bond formation, according to a similar natural reversible reaction (Scheme 1). Here we report on the stereoselective synthesis

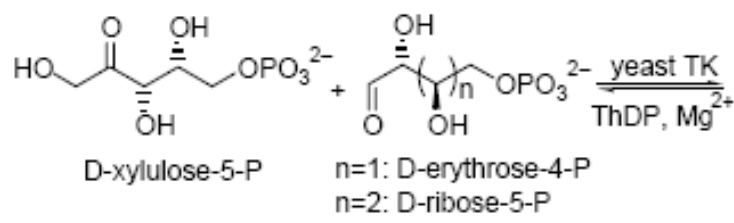
$n=2$ : D-ribose-5-P<smiles>O=C[C@H](O)CO[R6](=O)O[Na]</smiles>

$n=1$ : D-fructose-6-P $n=2$ : D-sedoheptulose-7-P

Scheme 1. Natural reaction catalysed by transketolase.

Keywords: Enzyme evolution; Transketolase; Fuorogenic assays; $\mathrm{C}-\mathrm{C}$ bond formation; High throughput screening.

* Corresponding author. Tel.: + 33473407871 ; fax: +33473407717; e-mail: laurence.hecquet @univ-bpclermont.fr 


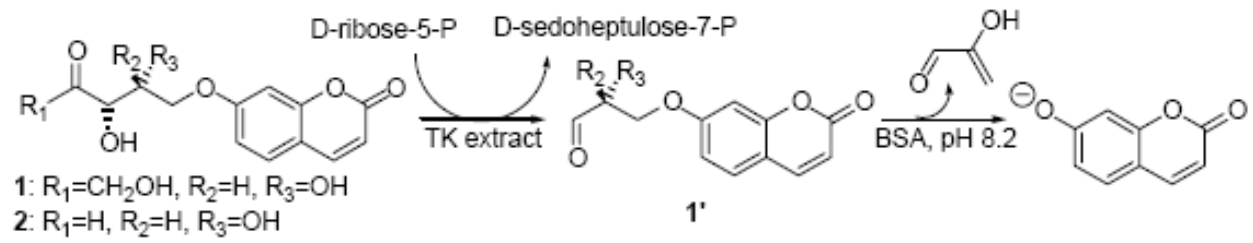

Scheme 2. Fuorescence assay based on umbelliferone release.

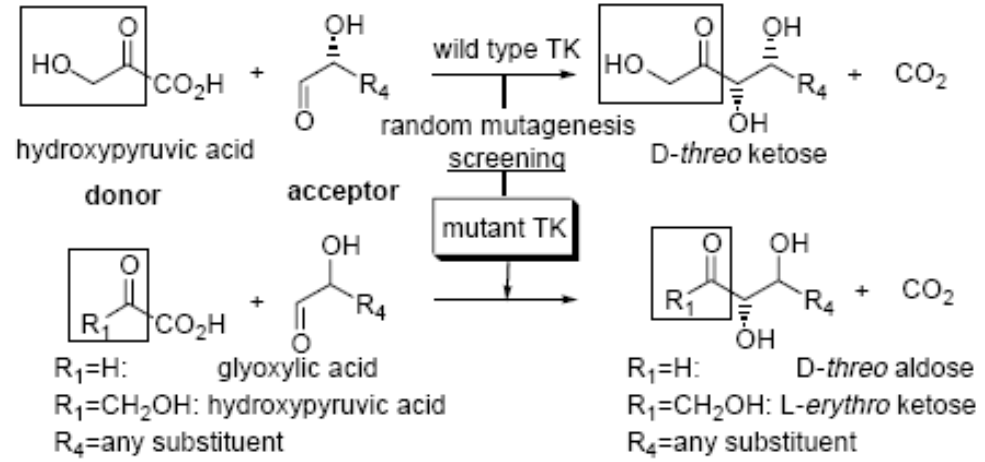

Scheme 3. Access to new D-threo-aldoses or L-erythro-ketoses by TK engineering.

of fluorogenic substrates as probes for measuring wild type or altered TK activity from variants with improved or new properties acquired by random mutagenesis.

\section{Results and discussion}

TK is a useful catalyst for ketoses syntheses. For this purpose, $\beta$-hydroxypyruvic acid was used as a donor substrate because it rendered the reaction imeversible. In this case, TK catalysed the irreversible transfer of a ketol unit from this donor substrate to various phosphorylated or non-phosphorylated aldehydes to generate $\mathrm{D}$-threo $(3 S, 4 R)$ ketoses. TK isolated from spinach leaves, ${ }^{10}$ baker's yeast, ${ }^{11}$ Escherichia coli, ${ }^{12}$ were investigated. Morerecently, we used Saccharomyces cerevisiae recombinant TK. ${ }^{13}$

\subsection{Substrate design}

We have shown the possibility of measuring wild type TK activity from $S$. cerevisiae using the suitable stereoselective fluorogenic substrate 1. ${ }^{14}$ This compound (Scheme 2) was used as a donor substrate of the enzyme in the presence of D-ribose-5-phosphate as an acceptor substrate. TK cleaved the $\mathrm{C}_{2}-\mathrm{C}_{3}$ bond of $\mathbf{1}$ and generated $\mathbf{1}^{\prime}$. A fluorescent signal appeared because $\mathbf{1}^{\prime}$ underwent a rapid $\beta$-elimination catalysed by bovine serum albumin (BSA) to release umbelliferone, a highly fluorescent compound. Our goal is to use this assay in the evaluation of TK mutants generated by random mutagenesis with fluorogenic substrates containing a sugar moiety depending on the enzymatic property desired.

We would like to modify the substrate specificity of TK to extend its synthetic potential to the L-erythro ketoses and D-threo aldoses series (Scheme 3 ). In the latter case, variants of TK would be able to accept glyoxylic acid as the donor substrate yielding D-threo aldoses while in the former case, variants would be able to accept $(S)$-hydroxyaldehydes as acceptor substrates yielding L-erythro ketoses.

Here we report the stereoselective syntheses of the fluorogenic compounds $\mathbf{1 , 2}$ and $\mathbf{3}$ as stereochemical probes for de novo TK activities. Compound $\mathbf{2}$ should be suitable for evaluating altered selectivity for the donor substrate, while compound $\mathbf{3}$ should be suitable for evaluating altered stereoselectivity for the acceptor substrate.

\subsection{Synthesis}

As previously described, ${ }^{14}$ the fluorogenic compound $\mathbf{1}$ was prepared by a chemoenzymatic route from the known umbelliferone (Scheme 4). Olefin 4 was obtained in $96 \%$ yield after allylation in refluxing acetone. ${ }^{15}$ As reported in the literature, ${ }^{16}$ aldehyde $\mathbf{5}$ was obtained by a two-step procedure using $\mathrm{OsO}_{4} / \mathrm{NMMO}$ to give the diol followed by overoxidation by $\mathrm{NaIO}_{4}$. To carry out the reaction in a single step, we performed an ozonolysis of crude $\mathbf{4}$ at $-30{ }^{\circ} \mathrm{C}$ in methylene chloride with $10 \%$ DMF. Reduction of the ozonide intermediate with dimethyl sulfide gave the aldehyde $\mathbf{5}$ in $62 \%$ yield with high selectivity for the exocyclic double bond versus the conjugated lactone double bond.

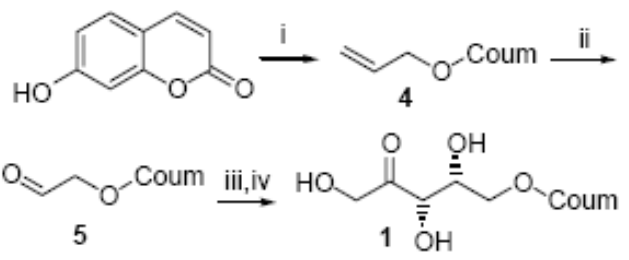

Scheme 4. Synthesis of 1: (i) $\mathrm{CH}_{2}=\mathrm{CH}-\mathrm{CH}_{2} \mathrm{Br}, \mathrm{K}_{2} \mathrm{CO}_{3},(4,96 \%)$; (ii) $\mathrm{O}_{3}$, $\mathrm{Me}_{2} \mathrm{~S},(5,62 \%)$; (iii) RAMA, DHAP, mCD; (iv) acid phosphatase, (1, 35\% overall for the last two steps). 
Our strategy was to introduce both chiral centers $(3 S, 4 R)$ of the sugar moiety of the fluorogenic substrate 1 at once, by using fructose-1,6-bisphosphate aldolase from rabbit muscle (RAMA; E.C.4.1.2.13). The utility of this enzyme is well-documented ${ }^{17}$ for the synthesis of D-threo ketoses by $\mathrm{C}-\mathrm{C}$ bond formation in a highly stereoselective manner. Aldehyde $\mathbf{5}$ thus underwent aldol addition using RAMA with dihydroxyacetone phosphate (DHAP) as the donor substrate (DHAP was prepared and assayed according to Chamantray et al. ${ }^{18}$ ). Because of the high hydrophobicity of the coumarin part of the molecule, we added a modified cyclodextrin (mCD) to make the aldehyde water-soluble. In these conditions, the reaction proceeded smoothly giving higher yields than using co-solvents such as DMSO or $\mathrm{MeOH}$. After dephosphorylation catalysed by acid phophatase (E.C.3.1.3.2) at pH 4.8, compound 1 was obtained in $35 \%$ overall yield for the two enzymatic steps.

To obtain compound $\mathbf{2}$, we investigated the use of commercially available D-dimethyl tartrate $(2 S, 3 S)$ as a building block to set the chirality on $\mathrm{C}_{2}$ and $\mathrm{C}_{3}$ at an early stage (Scheme 5).
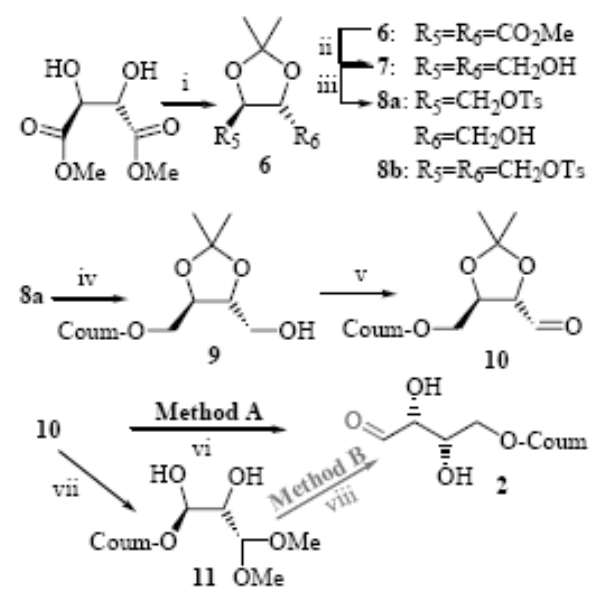

Scheme 5. Synthesis of 2: (i) $\left(\mathrm{CH}_{3}\right)_{2} \mathrm{C}\left(\mathrm{OCH}_{3}\right)_{2}(6,85 \%)$; (ii) $\mathrm{NaBH}_{4}(7$, $73 \%$ ); (iii) $\mathrm{TsCl}, \mathrm{NaOH}(8,83 \%)$; (iv) Coum-OH, $\mathrm{NaH}(9,71 \%)$; (v) DessMartin periodinane $(10,49 \%)$; (vi) Dowex $\mathrm{H}^{+}$resin $(2,25 \%)$; (vii) Dowex $\mathrm{H}^{+}$resin $(11,43 \%)$; (viii) Dowex $\mathrm{H}^{+}$resin $(2,28 \%)$.

Compound 8a was easily obtained from D-dimethyl tartrate $(2 S, 3 S)$ in a three-step sequence. Intermediate 6 was synthesised by transacetalisation in dimethoxypropane in $85 \%$ yield as described in the literature. ${ }^{19 a}$ Subsequent reduction of the diester was achieved using 1.5 equiv of $\mathrm{NaBH}_{4}$ in ethanol instead of 2.0 equiv in methanol. ${ }^{19 \mathrm{~b}}$ In this way, the yield of compound 7 was increased from 30 to $73 \%$ without significant transesterification.

Monotosylation of compound 7 was described earlier in $89 \%$ yield. ${ }^{20}$ Following this procedure, we failed to obtain 7 in more than $57 \%$ yield. Both increasing reaction time at room temperature to $5 \mathrm{~h}$ from $45 \mathrm{~min}$ and introducing strictly 1 equiv of tosyl chloride as the tosylating agent, we succesfully obtained compound $8 \mathrm{a}$ in $83 \%$ yield along with $10 \%$ of the corresponding bistosylated compound $\mathbf{8 b}$, which were separable by column chromatography.
At this stage, it was necessary to convert the primary alcohol function from 8a into a coumarinyl ether. We chose the sodium salt of umbelliferone as the nucleophile to substitute the tosylate $\mathbf{8 a}$, as described by Gonzalez-Garcia et al. ${ }^{9}$ for the synthesis of 6-O-coumarinyl D-fructose from protected D-fructose furanoside. The new compound 9 was recovered in $71 \%$ yield after purification. None of our attempts to increase the yield by either modifying the reaction temperature $\left(60,70\right.$ and $\left.90^{\circ} \mathrm{C}\right)$ or changing the counterion (from sodium to tert-butyl ammonium) (1) $^{21}$ was successful.

Oxidation of alcohol 9 was carried out using various oxidising reagents. Neither $\mathrm{CrO}_{3} / \mathrm{Pyr}$ nor $\mathrm{PCC} / \mathrm{NaOAc}$ gave any desired product, whereas Dess-Martin periodinane or $\mathrm{Pyr}-\mathrm{SO}_{3} / \mathrm{DMSO} / \mathrm{NEt}_{3}$ gave compound $\mathbf{1 0}$ with similar yields $(50 \%)$. In these latter conditions, reaction monitoring by TLC showed that the starting material was fully converted to the aldehyde $\mathbf{1 0}$ but the moderate yield may be explained by the instability of compound $\mathbf{1 0}$ on silica gel during purification by chromatography. Finally, this step was achieved using the easily handled periodinane reagent.

The final step dealt with the deprotection of the diol $\mathbf{1 0}$. We tried several usual acidic conditions such as AcOH, TFA, $\mathrm{HCl}$, and Dowex $\mathrm{H}^{+}$resin to hydrolyse the acetonide. We noted that when using $\mathrm{AcOH}, \mathrm{TFA}$, and $\mathrm{HCl}$ in water, compound $\mathbf{1 0}$ was fully dissolved, whereas when Dowex $\mathrm{H}^{+}$resin was used in water, it was necessary to add a minimum amount of co-solvent to obtain a clear solution. The co-solvents used were DMSO, THF, MeOH and acetone. Only the combination of Dowex $\mathrm{H}^{+}$resin in acetone $/ \mathrm{H}_{2} \mathrm{O}$ at room temperature gave compound 2 in $25 \%$ yield (method A). It is noteworthy that when the reaction was carried out in the same conditions but in $\mathrm{MeOH} / \mathrm{H}_{2} \mathrm{O}$ as the solvent mixture, we characterised compound $\mathbf{1 1}$ as a single product resulting from the deprotection of the diol with concomitant acetalisation of the aldehyde 2 . We tried to increase the yield of compound $\mathbf{1 1}$ by using larger amounts of $\mathrm{MeOH}$ to favour the acetal formation. The highest yield of $11(43 \%)$ was obtained with Dowex $\mathrm{H}^{+}$ resin in $\mathrm{MeOH} / \mathrm{H}_{2} \mathrm{O}$ 99:1 as the solvent mixture. We thus investigated the deprotection of $\mathbf{1 1}$ as an alternative route to compound 2 (method B). For that purpose, we followed the same conditions as described for the reaction of $\mathbf{1 0}$ to $\mathbf{2}$. Starting from 11, we obtained compound 2 in $28 \%$ yield. Due to its propensity to oligomerise because of the presence of a hydroxy group alpha to a carbonyl, compound $\mathbf{2}$ was recovered in moderate yields whatever the route followed. It was characterised by NMR and HRMS. The presence of the aldehyde function was confirmed by derivatisation to the corresponding diphenylhydrazone $\mathbf{2}^{\prime}$ according to the protocol described by Friestad et al. ${ }^{22}$

The synthesis of substrate $\mathbf{3}$ started from inexpensive D-ribose, useful for setting both $\mathrm{C}_{3}$ and $\mathrm{C}_{4}$ chirality in the final product ${ }^{9}$ (Scheme 6). The first steps required prior protection of the two secondary alcohols in acetonide $\mathbf{1 2}$ followed by protection of the primary one in a silylated derivative according to the literature. ${ }^{23-26}$ Compound $\mathbf{1 3}$ thus obtained was converted into $\mathbf{1 4}$ after ring opening by reduction over sodium borohydride in ethanol. ${ }^{27}$ 

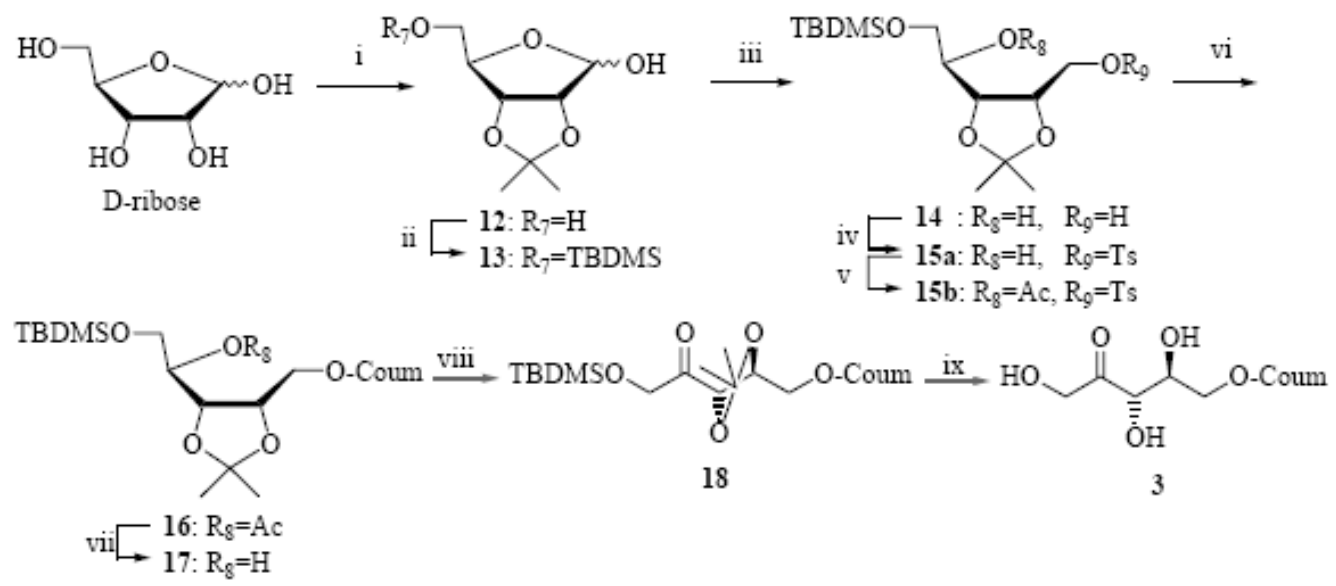

Scheme 6. Synthesis of 3: (i) acetone, PTSA, (12, 63\%); (ii) TBDMSCl, imidazole, (13, 71\%); (iii) $\mathrm{NaBH}_{4},(14,80 \%)$; (iv) TsCl, NEt 3 , DMAP, (15a, not isolated) then (v) $\mathrm{Ac}_{2} \mathrm{O}, \mathrm{NEt}_{3}$, (15b, $53 \%$ overall); (vi) $n \mathrm{Bu} \mathrm{u}_{4} \mathrm{NBr}$, umbelliferone, $\mathrm{NaOH},(16,60 \%)$; (vii) $\mathrm{K}_{2} \mathrm{CO}_{3}$, (17, 90\%); (viii) Dess-Martin reagent, $(18,74 \%)$; (ix) $\mathrm{I}_{2}, \mathrm{MeOH},(3,56 \%)$.

At this stage, it was necessary to activate selectively the primary alcohol function of $\mathbf{1 4}$ into a tosyl group. In our case, neither the use of $\mathrm{NaOH}^{28}$ nor $\mathrm{NEt}_{3} / \mathrm{DMAP}^{29}$ as bases gave satisfactory yields. The tosylated compound 15a was obtained in the reaction mixture but was sensitive to intramolecular cyclisation by nucleophilic attack of the free secondary alcohol on the tosyl group, leading to a furan type compound. As this side reaction occurred mainly during workup, this unwanted reaction was prevented by protecting the free secondary alcohol as an acetyl group directly in the reaction medium, just after formation of the tosyl derivative. Compound $\mathbf{1 5 b}$ was then obtained in satisfactory yield (53\% overall).

The tosyl displacement by umbelliferone was first attempted using the protocol described by Gonzalez-Garcia et al., ${ }^{10}$ that is, using $\mathrm{NaH}$ as base. Unfortunately, in our case, these conditions suffered from appearance of many byproducts resulting of a loss of silylated protecting group.

Finally, we chose to make the tetrabutylammonium salt of umbelliferone beforehand following the procedure described by Vasela et al. ${ }^{21}$ to carry out the intermolecular nucleophilic substitution in neutral conditions at a lower reaction temperature. This gave the desired product $\mathbf{1 6}$ in $60 \%$ yield. A single alkaline hydrolysis of the acetyl group followed by an oxidation using the smooth Dess-Martin reagent ${ }^{30}$ then gave $\mathbf{1 8}$ in $67 \%$ overall yield. Usual acidic hydrolysis of all the remaining protective groups using acidic resin, TFA or $\mathrm{HCl}$ in various co-solvents to solubilise the starting material $(\mathrm{MeOH}$, acetone, DMF) at different reaction temperatures ranging from room temperature to $65^{\circ} \mathrm{C}$ (the degradation threshold temperature) failed to give product 3 . The ether bond proved to be easily cleaved causing umbelliferone release. The highest yield $(56 \%)$ was obtained using iodine in methanol, ${ }^{31}$ an alternative method for the cleavage of acetals into carbohydrate derivatives, leading to the final L-erythro ketose $\mathbf{3}$.

\subsection{Yeast TK fluorogenic assays}

Assay conditions were optimised with wild type $\mathrm{TK}^{14}$ and fluorogenic compound $\mathbf{1}$, bearing the glycosyl moiety of
D-threo ketose configuration as the donor substrate. The reaction proceeded in the presence of D-ribose-5-phosphate as acceptor substrate, thiamine pyrophosphate and $\mathrm{Mg}^{2+}$ as cofactors and BSA as catalyst for umbelliferone $\beta$-elimination in Tris buffer $(\mathrm{pH} \mathrm{8.2)}$. We observed a fluorescent signal proportional to both TK quantity and compound 1 concentration. ${ }^{14}$ Under the same conditions, fluorogenic compounds $\mathbf{2}$ and $\mathbf{3}$ bearing, respectively, D-threo aldose and L-erythro ketose moieties did not lead to a significant fluorescence signal in the presence of wild type TK. This experiment showed that wild type TK was able to discriminate between the natural (D-threo) configuration of compound $\mathbf{1}$ and the non-natural (L-erythro) configuration of compound 3. Moreover, TK was able to discriminate between the natural hydroxyacetyl moiety of $\mathbf{1}$, mimicking the natural substrate, and the non-natural formyl moiety of $\mathbf{2}$.

\section{Conclusion}

In conclusion, three stereochemical fluorogenic probes for transketolase have been prepared. The fluorogenic compound 1 with natural $\mathrm{D}$-threo ketose configuration enabled us to design a highly sensitive fluorogenic assay for wild type TK, in the presence of BSA as auxiliary protein. Our interest was to modify the substrate specificity of TK by random mutagenesis. In this field, the principle of this stereospecific fluorogenic assay could be used to screen TK variants able to recognize the $\mathrm{D}$-threo aldose (compound 2 ) and L-erythro ketose (compound 3 ) moieties. Some experiments in this field are currently under investigation.

\section{Experimental}

\subsection{General information}

Chemicals and solvents were purchased from Aldrich and Acros and were reagent grade. Rabbit muscle aldolase (E.C.4.1.2.13), acid phosphatase (E.C.3.1.3.2) from wheat germ and BSA were purchased from Sigma. Transketolase from $S$. cerevisiae was produced and purified by us as 
previously described. ${ }^{32}$ Merck 60 F254 silica gel TLC plates and Merck 60/230-400 and 60/40-63 mesh silica gel for column chromatography were used. ${ }^{1} \mathrm{H}$, and ${ }^{13} \mathrm{C}$ NMR spectra were recorded on a Bruker Avance 400 spectrometer in $\mathrm{CDCl}_{3}, \mathrm{D}_{2} \mathrm{O}, \mathrm{CD}_{3} \mathrm{OD}$ and $\mathrm{CD}_{3} \mathrm{COCD}_{3}, \delta$ values are given in parts per million and $J$ values in Hertz. MS and HRMS were recorded on a Micromass Q-Tof spectrometer equipped with an electrospray ionisation source. Optical rotations were determined on a Jasco DIP-370 polarimeter using a $10 \mathrm{~cm}$ cell. Melting points are uncorrected and were measured on a Reichert apparatus.

4.1.1. 7-(2-Oxoethoxy) coumarine (5). Eight hundred and sixty milligrams of compound $4(4.57 \mathrm{mmol})$ was dissolved in $2 \mathrm{~mL}$ of DMF and $20 \mathrm{~mL}$ of dichloromethane at room temperature, and then cooled to $-40{ }^{\circ} \mathrm{C}$ and treated with a stream of ozone. When the reaction was complete as seen by TLC using cyclohexane/ethyl acetate $2: 8$, ozone was removed by flushing with an argon stream for $1 \mathrm{~h} .1 \mathrm{~mL}$ of dimethylsulfide ( $13.4 \mathrm{mmol}, 3$ equiv) was added dropwise at $-40{ }^{\circ} \mathrm{C}$. The reaction mixture was then wamed to room temperature overnight and evaporated under vacuum. The crude material was dissolved in $50 \mathrm{~mL}$ of ethyl acetate and washed five times with $50 \mathrm{~mL}$ of water. After evaporation under vacuum, the product was chromatographed on silica gel using cyclohexane/ethyl acetate $1: 1$ as eluent. $560 \mathrm{mg}$ of compound $\mathbf{5}$ was obtained as a white solid in $64 \%$ yield. The analytical data for characterisation are similar to those already reported in the literature. ${ }^{16}$

4.1.2. $7-\left(2^{\prime}, 3^{\prime}, 5^{\prime}\right.$-Trihydroxy-4 $4^{\prime}$ oxo-pentyl $)$ oxy coumarine (1). $0.878 \mathrm{~g}$ of (2-Hydroxypropyl)- $\beta$-cyclodextrin $(0.63 \mathrm{mmol})$ and $100 \mathrm{mg}(0.53 \mathrm{mmol}, 1.2$ equiv) of 7 (2-oxoethoxy)coumarin $\mathbf{5}$ were dissolved in $3.9 \mathrm{~mL}$ of methanol and stirred for $15 \mathrm{~min}$. $2.6 \mathrm{~mL}$ of water were added and the methanol was evaporated. $1.3 \mathrm{~mL}$ of a DHAP solution ( $400 \mathrm{mM}, 0.53 \mathrm{mmol}, 1$ equiv, $\mathrm{pH} 7.8$ ) were then poured in (to give a $200 \mathrm{mM}$ final substrate concentration) followed by $150 \mathrm{U}$ of commercially available RAMA. The mixture was stirred for $48 \mathrm{~h}$ at room temperature. The reaction was followed by TLC with 1-propanol/ethylacetate/ water/ethanol/pyridine/acetic acid $35: 15: 25: 15: 10: 10$ as eluent until complete disappearance of the starting aldehyde. The $\mathrm{pH}$ was adjusted to 4.8 and $150 \mathrm{U}$ of acid phosphatase was added. The mixture was then stirred overnight. Three volumes of methanol were added to precipitate proteins, the mixture was centrifuged at $8000 \mathrm{rpm}$ and the subsequent supernatant was evaporated to dryness under vacuum. Two flash chromatographies (methylene chloride/methanol 9:1) gave $56 \mathrm{mg}$ of compound $\mathbf{1}$ as a white solid (35\% yield).

${ }^{1} \mathrm{H}$ NMR $\left(\mathrm{CD}_{3} \mathrm{COCD}_{3}, 400 \mathrm{MHz}\right) \delta(\mathrm{ppm}): 4.15(1 \mathrm{H}, \mathrm{dd}$, $\left.J_{1^{\prime}-2^{\prime}}=6.2 \mathrm{~Hz}, J_{1^{\prime}-1^{m}}=9.8 \mathrm{~Hz}, \mathrm{H}_{1^{\prime}}\right), 4.26\left(1 \mathrm{H}, \mathrm{dd}, J_{1^{\prime}-2}=\right.$ $\left.6.2 \mathrm{~Hz}, J_{1^{\prime \prime}-1^{\prime}}=9.8 \mathrm{~Hz}, \mathrm{H}_{1^{\prime \prime}}\right), 4.40\left(1 \mathrm{H}, \mathrm{td}, J_{2^{\prime}-3^{\prime}}=2.4 \mathrm{~Hz}\right.$, $\left.J_{2^{\prime}-1^{\prime}}=6.2 \mathrm{~Hz}, J_{2^{\prime}-1^{\prime \prime}}=6.2 \mathrm{~Hz}, \mathrm{H}_{2^{\prime}}\right), 4.45\left(1 \mathrm{H}, \mathrm{d}, J_{5^{\prime}-5^{\prime}}=\right.$ $\left.19.6 \mathrm{~Hz}, \mathrm{H}_{5^{\prime}}\right), 4.50\left(1 \mathrm{H}, \mathrm{d}, J_{3^{\prime}-2^{\prime}}=2.4 \mathrm{~Hz}, \mathrm{H}_{3^{\prime}}\right), 4.55(1 \mathrm{H}, \mathrm{d}$, $\left.J_{5^{i}-5^{\prime}}=19.6 \mathrm{~Hz}, \mathrm{H}_{5^{n}}\right), 6.20\left(1 \mathrm{H}, \mathrm{d}, J_{3-4}=9.2 \mathrm{~Hz}, \mathrm{H}_{3}\right), 6.8$ $\left(1 \mathrm{H}, \mathrm{s}, \mathrm{H}_{8}\right), 6.9\left(1 \mathrm{H}, \mathrm{d}, J_{6-5}=8.5 \mathrm{~Hz}, \mathrm{H}_{6}\right), 7.54(1 \mathrm{H}, \mathrm{d}$, $\left.J_{5-6}=8.5 \mathrm{~Hz}, \mathrm{H}_{5}\right), 7.87\left(1 \mathrm{H}, \mathrm{d}, J_{4-3}=9.2 \mathrm{~Hz}, \mathrm{H}_{4}\right) .{ }^{13} \mathrm{C} \mathrm{NMR}$ $\left(\mathrm{CD}_{3} \mathrm{COCD}_{3}, 100 \mathrm{MHz}\right) \delta(\mathrm{ppm}): 66.8\left(\mathrm{C}_{5^{\prime}}\right), 68.9\left(\mathrm{C}_{1^{\prime}}\right)$, $70.1\left(\mathrm{C}_{2^{\prime}}\right), 75.7\left(\mathrm{C}_{3^{\prime}}\right), 101.3\left(\mathrm{C}_{6}\right), 112.5\left(\mathrm{C}_{8}\right), 112.7\left(\mathrm{C}_{9}\right)$, $112.8\left(\mathrm{C}_{3}\right), 129.3\left(\mathrm{C}_{5}\right), 143.7\left(\mathrm{C}_{4}\right), 155.8\left(\mathrm{C}_{10}\right), 160.1\left(\mathrm{C}_{7}\right)$,
$161.9\left(\mathrm{C}_{2}\right), 211.9\left(\mathrm{C}_{4^{\prime}}\right)$. HRMS (ESI+) calculated for $\mathrm{C}_{14} \mathrm{H}_{15} \mathrm{O}_{7}:[\mathrm{M}+\mathrm{H}]^{+} 295.0818$, found 295.0823 .

4.1.3. 2,3-O-Isopropylidene-1-tosyl-D-threitol (8b). This compound was synthesised according to the method of Valverde et al. ${ }^{20}$ Starting from $2.77 \mathrm{~g}(17.1 \mathrm{mmol})$ of compound 7, we recovered compound $\mathbf{8 a}$, isolated in $83 \%$ yield as a colourless oil (4.48 g, $14.2 \mathrm{mmol})$ after column chromatography. Bistosylated compound $\mathbf{8 b}$ was also isolated from the crude product in $10 \%$ yield.

4.1.4. 2,3-Isopropyliden-1-O-( $2^{\prime}$-oxo-benzopy ran- $7^{\prime}$-yl $)$-D (9). To a solution of $1.25 \mathrm{~g}$ of umbelliferone $(7.73 \mathrm{mmol}$, 1.5 equiv) in $30 \mathrm{~mL}$ of DMF under nitrogen was dissolved $0.31 \mathrm{~g}$ of sodium hydride ( $60 \%$ oil dispersion, $7.73 \mathrm{mmol}$, 1.5 equiv). The mixture was stirred at room temperature for $1 \mathrm{~h}$. A mixture of compound $8 \mathrm{~b}(1.63 \mathrm{~g}, 5.15 \mathrm{mmol}$, 1 equiv) in DMF (12 mL) was then added. The reaction mixture was then heated under stirring at $80^{\circ} \mathrm{C}$ and was followed by TLC (cyclohexane/AcOEt 4:6) until complete disappearance of the starting material $(18 \mathrm{~h})$. After extraction with ethyl acetate, the collected organic phases were washed with brine and evaporated under reduced pressure. The title compound 9 was purified from the crude product by column chromatography on silica gel, eluted in cyclohexane/AcOEt 6:4, 5:5, 4:6 gradient. Compound 9 was recovered as white needles $(1.12 \mathrm{~g}, 3.65 \mathrm{mmol})$ in $71 \%$ yield.

TLC: $R_{\mathrm{f}}$ (cyclohexane/AcOEt $\left.4: 6\right)=0.30 .[\alpha]_{\mathrm{D}}^{22} 24.3(c$ 1.01, acetone). Mp $79-83{ }^{\circ} \mathrm{C} .{ }^{1} \mathrm{H}$ NMR $\left(400 \mathrm{MHz}, \mathrm{CDCl}_{3}\right)$ $\delta: 1.45\left(6 \mathrm{H}, 2 \mathrm{~s}, 2 \mathrm{H}_{6}\right), 2.31(1 \mathrm{H}, \mathrm{s}, 1 \mathrm{OH}), 3.75(1 \mathrm{H}, \mathrm{dd}$, $\left.J_{4-3}=4 \mathrm{~Hz}, J_{4-4^{\prime}}=12 \mathrm{~Hz}, \mathrm{H}_{4}\right), 3.88\left(1 \mathrm{H}, \mathrm{dd}, J_{4^{\prime}-3}=4 \mathrm{~Hz}\right.$, $\left.J_{4^{\prime}-4}=12 \mathrm{~Hz}, \mathrm{H}_{4^{\prime}}\right), 4.10\left(1 \mathrm{H}\right.$, ddd, $J_{3-4}=4 \mathrm{~Hz}, J_{3-4^{\prime}}=4 \mathrm{~Hz}$, $\left.J_{3-2}=8 \mathrm{~Hz}, \mathrm{H}_{3}\right), 4.14\left(1 \mathrm{H}, \mathrm{dd}, J_{1-2}=5 \mathrm{~Hz}, J_{1-1^{\prime}}=10 \mathrm{~Hz}\right.$, $\left.\mathrm{H}_{1}\right), 4.18\left(1 \mathrm{H}, \mathrm{dd}, J_{1^{\prime}-2}=5 \mathrm{~Hz}, J_{1^{\prime}-1}=10 \mathrm{~Hz}, \mathrm{H}_{1^{\prime}}\right), 4.31(1 \mathrm{H}$, ddd, $\left.J_{2-1}=5 \mathrm{~Hz}, J_{2-1^{\prime}}=5 \mathrm{~Hz}, J_{2-3}=8 \mathrm{~Hz}, \mathrm{H}_{2}\right), 6.24(1 \mathrm{H}$, d, $\left.J_{3^{\prime}-4^{\prime}}=10 \mathrm{~Hz}, \mathrm{H}_{3^{\prime}}\right), 6.81\left(1 \mathrm{H}, \mathrm{s}, \mathrm{H}_{8^{\prime}}\right), 6.85\left(1 \mathrm{H}, \mathrm{d}, J_{6^{\prime}-5^{\prime}}=\right.$ $\left.8 \mathrm{~Hz}, \mathrm{H}_{6^{\prime}}\right), 7.35\left(1 \mathrm{H}, \mathrm{d}, J_{5^{\prime}-6^{\prime}}=8 \mathrm{~Hz}, \mathrm{H}_{5^{\prime}}\right), 7.62(1 \mathrm{H}, \mathrm{d}$, $\left.J_{4^{\prime}-3^{\prime}}=10 \mathrm{~Hz}, \mathrm{H}_{4^{\prime}}\right) .{ }^{13} \mathrm{C}$ NMR $\left(100 \mathrm{MHz}, \mathrm{CDCl}_{3}\right) \delta: 27.0$ $\left(2 \mathrm{C}_{6}\right), 62.2\left(\mathrm{C}_{4}\right), 68.9\left(\mathrm{C}_{1}\right), 75.5\left(\mathrm{C}_{3}\right), 78.6\left(\mathrm{C}_{2}\right), 101.7\left(\mathrm{C}_{6^{\prime}}\right)$, $110.7\left(\mathrm{C}_{5}\right), 112.9\left(\mathrm{C}_{8^{\prime}}\right), 113.0\left(\mathrm{C}_{9^{\prime}}\right), 113.5\left(\mathrm{C}_{3^{\prime}}\right), 128.9\left(\mathrm{C}_{5^{\prime}}\right)$, $143.5\left(\mathrm{C}_{4^{\prime}}\right), 155.8\left(\mathrm{C}_{10^{\prime}}\right), 161.2\left(\mathrm{C}_{7^{\prime}}\right), 161.7\left(\mathrm{C}_{2^{\prime}}\right)$. HRMS $\left(\mathrm{ESI}^{+}\right) \mathrm{m} / \mathrm{z}:\left[\mathrm{M}+\mathrm{H}^{+}\right]$: calculated for $\mathrm{C}_{16} \mathrm{H}_{19} \mathrm{O}_{6} 307.1182$, found 307.1195 .

4.1.5. 2,3-Isopropyliden-4- $O$ - $\left(2^{\prime}\right.$-oxo-benzopyran- $7^{\prime}$-yl $)$ D-threose (10). A cold $\left(4^{\circ} \mathrm{C}\right) 15 \%$ solution of Dess-Martin periodinane in $\mathrm{CH}_{2} \mathrm{Cl}_{2}$ ( $800 \mu \mathrm{L}, 1.2$ equiv) was added to a solution of compound 9 ( $97 \mathrm{mg}, 0.32 \mathrm{mmol}, 1$ equiv) in dichloromethane $(6.3 \mathrm{~mL})$ at $5{ }^{\circ} \mathrm{C}$. The reaction mixture was kept at $5{ }^{\circ} \mathrm{C}$ with stirring for $2 \mathrm{~h}$, and then poured into an ice- $0.1 \mathrm{~N} \mathrm{NaHCO}_{3}$ mixture $(20 \mathrm{~mL})$. After 3 extractions with ethyl acetate, the organic layer was successively washed with $0.1 \mathrm{~N} \mathrm{NaHCO}_{3}$ and brine. It was then dried on $\mathrm{MgSO}_{4}$. After evaporation under reduced pressure the crude residue was purified by flash chromatography on silica gel (cyclohexane/AcOEt 1:1). Compound 10 (43 mg, $0.14 \mathrm{mmol}$ ) was isolated as white needles in $50 \%$ yield.

TLC: $R_{\mathrm{f}}$ (cyclohexane/AcOEt $\left.4: 6\right)=0.30 . \mathrm{Mp} 67-69^{\circ} \mathrm{C}$. $[\alpha]_{\mathrm{D}}^{25} 4.95$ (c 1.07, chloroform). ${ }^{1} \mathrm{H}$ NMR $(400 \mathrm{MHz}$, $\left.\mathrm{CDCl}_{3}\right) \delta: 1.50\left(6 \mathrm{H}, 2 \mathrm{~s}, 2 \mathrm{H}_{6}\right), 4.19\left(1 \mathrm{H}, \mathrm{dd}, J_{4 \mathrm{a}-3}=5 \mathrm{~Hz}\right.$, 
$\left.J_{4 \mathrm{a}-4 \mathrm{~b}}=10 \mathrm{~Hz}, \mathrm{H}_{4 \mathrm{a}}\right), 4.26\left(1 \mathrm{H}, \mathrm{dd}, J_{4 \mathrm{~b}-3}=4 \mathrm{~Hz}, J_{4 \mathrm{~b}-4}=\right.$ $\left.10 \mathrm{~Hz}, \mathrm{H}_{4^{\prime}}\right), 4.36\left(1 \mathrm{H}, \mathrm{d}, J_{2-3}=7 \mathrm{~Hz}, \mathrm{H}_{2}\right), 4.47\left(1 \mathrm{H}, \mathrm{m}, \mathrm{H}_{3}\right)$, $6.27\left(1 \mathrm{H}, \mathrm{d}, J_{3^{\prime}-4^{\prime}}=10 \mathrm{~Hz}, \mathrm{H}_{3^{\prime}}\right), 6.84\left(1 \mathrm{H}, \mathrm{s}, \mathrm{H}_{8^{\prime}}\right), 6.87(1 \mathrm{H}$, d, $\left.J_{6^{\prime}-5^{\prime}}=9 \mathrm{~Hz}, \mathrm{H}_{6^{\prime}}\right), 7.38\left(1 \mathrm{H}, \mathrm{d}, J_{5^{\prime}-6^{\prime}}=9 \mathrm{~Hz}, \mathrm{H}_{5^{\prime}}\right), 7.63$ $\left(1 \mathrm{H}, \mathrm{d}, J_{4^{\prime}-3^{\prime}}=10 \mathrm{~Hz}, \mathrm{H}_{4^{\prime}}\right), 9.85\left(1 \mathrm{H}, \mathrm{s}, \mathrm{H}_{1}\right) .{ }^{13} \mathrm{C} \mathrm{NMR}$ $\left(100 \mathrm{MHz}, \mathrm{CDCl}_{3}\right) \delta: 26.4,26.7\left(2 \mathrm{C}_{6}\right), 68.2\left(\mathrm{C}_{4}\right), 75.3\left(\mathrm{C}_{3}\right)$, $81.5\left(\mathrm{C}_{2}\right), 101.8\left(\mathrm{C}_{6^{\prime}}\right), 112.2\left(\mathrm{C}_{5}\right), 112.8\left(\mathrm{C}_{8^{\prime}}\right), 113.5\left(\mathrm{C}_{9^{\prime}}\right)$, $113.6\left(\mathrm{C}_{3^{\prime}}\right), 128.9\left(\mathrm{C}_{5^{\prime}}\right), 143.3\left(\mathrm{C}_{4^{\prime}}\right), 155.7\left(\mathrm{C}_{10^{\prime}}\right), 161.0$ $\left(\mathrm{C}_{7^{\prime}}\right), 161.4\left(\mathrm{C}_{2^{\prime}}\right), 200.8\left(\mathrm{C}_{1}\right)$. HRMS $\left(\mathrm{ESI}^{+}\right) \mathrm{m} / \mathrm{z}:[\mathrm{M}+$ $\mathrm{H}^{+}$]: calculated for $\mathrm{C}_{16} \mathrm{H}_{17} \mathrm{O}_{6} 305.1025$, found 305.1035 .

4.1.6. 2,3-Dihydroxy-1,1-dimethylacetal-4-O-(2'-oxobenzopyran- $7^{\prime}$-yl)-D-threose (11). Fifty four milligrams (0.18 mmol, 1 equiv) of the starting compound was solubilised in $2 \mathrm{~mL}$ of methanol and $20 \mu \mathrm{L}$ of water. $1.5 \mathrm{~mL}$ of Dowex $\mathrm{H}^{+}$resin $(50 \mathrm{WX} 8-400)$ was then added and the reaction mixture allowed to stir for 2 days. The reaction was monitored by TLC using $\mathrm{CH}_{2} \mathrm{Cl}_{2} / \mathrm{MeOH}$ 9:1 as eluent. After completion of the reaction, the resin was removed by filtration and the mixture evaporated under vacuum. The white residue thus obtained was purified by flash chromatography on silica gel using $\mathrm{CH}_{2} \mathrm{Cl}_{2} / \mathrm{MeOH}$ 95:5 as eluent. Compound $\mathbf{1 1}$ was isolated in $43 \%$ yield as white crystals.

TLC: $R_{\mathrm{f}}(\mathrm{DCM} / \mathrm{MeOH} 9: 1)=0.75 . \mathrm{Mp} 112-114{ }^{\circ} \mathrm{C} .[\alpha]_{\mathrm{D}}^{25}$ $-7.8(c 0.92, \mathrm{MeOH}) .{ }^{1} \mathrm{H}$ NMR $\left(400 \mathrm{MHz} \mathrm{CDCl}_{3}\right) \delta: 2.75$ $(1 \mathrm{H}, \mathrm{s}, \mathrm{OH}), 2.92(1 \mathrm{H}, \mathrm{s}, \mathrm{OH}), 3.5\left(6 \mathrm{H}, 2 \mathrm{~s}, 2 \mathrm{H}_{5}\right), 3.72(1 \mathrm{H}$, dd, $\left.J_{2-3}=2 \mathrm{~Hz}, J_{2-1}=6 \mathrm{~Hz}, \mathrm{H}_{2}\right), 4.11\left(2 \mathrm{H}, \mathrm{d}, J_{4 \mathrm{a}-3}=6 \mathrm{~Hz}\right.$, $\left.\mathrm{H}_{4 \mathrm{a}}+\mathrm{H}_{4 \mathrm{~b}}\right), 4.23\left(1 \mathrm{H}, \mathrm{td}, J_{3-2}=2 \mathrm{~Hz}, J_{3-4 \mathrm{a}}=6 \mathrm{~Hz}, J_{3-4 \mathrm{~b}}=\right.$ $\left.6 \mathrm{~Hz}, \mathrm{H}_{3}\right), 4.50\left(1 \mathrm{H}, \mathrm{d}, J_{1-2}=6 \mathrm{~Hz}, \mathrm{H}_{1}\right), 6.23(1 \mathrm{H}, \mathrm{d}, J=$ $\left.10 \mathrm{~Hz}, \mathrm{H}_{3^{\prime}}\right), 6.82\left(1 \mathrm{H}, \mathrm{s}, \mathrm{H}_{8^{\prime}}\right), 6.85\left(1 \mathrm{H}, \mathrm{d}, J_{6^{\prime}-5^{\prime}}=9 \mathrm{~Hz}\right.$, $\left.\mathrm{H}_{6^{\prime}}\right), 7.34\left(1 \mathrm{H}, \mathrm{d}, J_{5^{\prime}-6^{\prime}}=9 \mathrm{~Hz}, \mathrm{H}_{5^{\prime}}\right), 7.61\left(1 \mathrm{H}, \mathrm{d}, J_{4^{\prime}-3^{\prime}}=\right.$ $\left.10 \mathrm{~Hz}, \mathrm{H}_{4^{\prime}}\right) .{ }^{13} \mathrm{C}$ NMR (100 MHz, $\left.\mathrm{CDCl}_{3}\right) \delta: 53.3,56.7$ $\left(2 \mathrm{C}_{5}\right), 68.5\left(\mathrm{C}_{3}\right), 69.6\left(\mathrm{C}_{4}\right), 70.2\left(\mathrm{C}_{2}\right), 101.9\left(\mathrm{C}_{6}\right), 105.4$ $\left(\mathrm{C}_{1}\right), 112.9\left(\mathrm{C}_{8^{\prime}}+\mathrm{C}_{9^{\prime}}\right), 113.3\left(\mathrm{C}_{3^{\prime}}\right), 128.9\left(\mathrm{C}_{5^{\prime}}\right), 143.5\left(\mathrm{C}_{4^{\prime}}\right)$, $155.8\left(\mathrm{C}_{10^{\prime}}\right), 161.3\left(\mathrm{C}_{7^{\prime}}\right), 161.9\left(\mathrm{C}_{2^{\prime}}\right)$. HRMS $\left(\mathrm{ESI}^{+}\right) \mathrm{m} / \mathrm{z}$ : $\left[\mathrm{M}+\mathrm{H}^{+}\right]$: calculated for $\mathrm{C}_{15} \mathrm{H}_{19} \mathrm{O}_{7} 311.1131$, found 311.1139 .

4.1.7. 2,3 Dihydroxy-4- $O$ - $\left(2^{\prime}\right.$-oxo-benzopyran- $7^{\prime}$-yl)-Dthreose (2). General method for acidic hydrolysis of acetals.

Acetal was dissolved in binary system (water/acetone $3: 1$ ). Dowex $\mathrm{H}^{+}$resin (50WX8-400) was added and the reaction suspension stirred. The suspension was refluxed for $1 \mathrm{~h}$ with stirring under reflux until completion (reaction monitored by TLC). After cooling to room temperature, the reaction mixture was filtered and washed with $1 \mathrm{~mL}$ of acetonewater mixture (1/2). Acetone was removed under reduced pressure and the $\mathrm{pH}$ of the water layer was adjusted to 7 with an Amberlite resin (IRA-93). After lyophilisation, the crude material was flash chromatographed on silica gel using $\mathrm{CH}_{2} \mathrm{Cl}_{2}-\mathrm{MeOH}(97 / 3)$ as the eluent. The final compound 2 was obtained as a colourless oil.

When compound $\mathbf{1 0}$ was used as the starting acetal, title compound 2 was recovered in $25 \%$ yield whereas conversion of compound $\mathbf{1 1}$ afforded compound $\mathbf{2}$ in $28 \%$ yield.

TLC: $R_{\mathrm{f}}\left(\mathrm{CH}_{2} \mathrm{Cl}_{2} / \mathrm{MeOH} 9: 1\right)=0.33 .[\alpha]_{\mathrm{D}}^{25} 1.84(c) 3.3$, chloroform). ${ }^{1} \mathrm{H}$ NMR $\left(400 \mathrm{MHz}, \mathrm{CD}_{3} \mathrm{OD}\right) \delta: 3.25-3.52$ $\left(1 \mathrm{H}, \mathrm{m}, \mathrm{H}_{2}\right), 3.54-4.13\left(3 \mathrm{H}, \mathrm{m}, \mathrm{H}_{3}+2 \mathrm{H}_{4}\right), 4.71(1 \mathrm{H}, \mathrm{d}$, $\left.J_{1-2}=6 \mathrm{~Hz}, \mathrm{H}_{1}\right), 6.14\left(1 \mathrm{H}, \mathrm{d}, J_{3^{\prime}-4^{\prime}}=9.6 \mathrm{~Hz}, \mathrm{H}_{3^{\prime}}\right), 6.83(1 \mathrm{H}$, $\left.\mathrm{s}, \mathrm{H}_{8^{\prime}}\right), 6.88\left(1 \mathrm{H}, \mathrm{d}, J_{6^{\prime}-5^{\prime}}=8.4 \mathrm{~Hz}, \mathrm{H}_{6^{\prime}}\right), 7.45\left(1 \mathrm{H}, \mathrm{d}, J_{5^{\prime}-6^{\prime}}=\right.$ $\left.8.4 \mathrm{~Hz}, \mathrm{H}_{5^{\prime}}\right), 7.77\left(1 \mathrm{H}, \mathrm{d}, J_{4^{\prime}-3^{\prime}}=9.6 \mathrm{~Hz}, \mathrm{H}_{4^{\prime}}\right) .{ }^{13} \mathrm{C}$ NMR $\left(100 \mathrm{MHz}, \mathrm{CD}_{3} \mathrm{OD}\right) \delta: 68.7\left(\mathrm{C}_{2}\right), 69.7\left(\mathrm{C}_{4}\right), 73.3\left(\mathrm{C}_{3}\right), 89.6$ $\left(\mathrm{C}_{1}\right.$, hydrate form $), 101.4\left(\mathrm{C}_{6^{\prime}}\right), 112.7\left(\mathrm{C}_{8^{\prime}}\right), 113.4\left(\mathrm{C}_{9^{\prime}}\right)$, $113.8\left(\mathrm{C}_{3^{\prime}}\right), 129.6\left(\mathrm{C}_{5^{\prime}}\right), 145.9\left(\mathrm{C}_{4^{\prime}}\right), 154.9\left(\mathrm{C}_{10^{\prime}}\right), 163.9$ $\left(\mathrm{C}_{2^{\prime}}+\mathrm{C}_{7^{\prime}}\right)$. HRMS $\left(\mathrm{ESI}^{+}\right) \mathrm{m} / \mathrm{z}:\left[\mathrm{M}+\mathrm{H}^{+}\right]$: calculated for $\mathrm{C}_{13} \mathrm{H}_{13} \mathrm{O}_{6} 265.0712$, found 265.0708 .

4.1.8. Derivatisation of compound 2 into the corresponding $N, N$-diphenylhydrazone $2^{\prime}$. To a solution of compound 2 (56 mg, $0.21 \mathrm{mmol}, 1$ equiv) in $4 \mathrm{~mL}$ of toluene were successively added $\mathrm{N}, \mathrm{N}$-diphenylhydrazine hydrochloride (94 mg; $0.42 \mathrm{mmol} ; 2$ equiv) and sodium sulphate $\mathrm{Na}_{2} \mathrm{SO}_{4}$ $(1.26 \mathrm{~g} ; 10.2 \mathrm{mmol})$ at room temperature. The reaction mixture was kept at room temperature under stirring for $24 \mathrm{~h}$. After filtration, the crude mixture was concentrated under vacuum, and purified by flash chromatography on silica gel (cyclohexane/AcOEt 6:4). Hydrazone $\mathbf{2}^{\prime}$ was recovered as a bright yellow oil in $36 \%$ yield.

TLC: $R_{\mathrm{f}}$ (cyclohexane/AcOEt $6: 4$ ) $=0.13 .{ }^{1} \mathrm{H}$ NMR $\left(400 \mathrm{MHz}, \mathrm{CDCl}_{3}\right) \delta: 2.63(1 \mathrm{H}, \mathrm{d}, J=5 \mathrm{~Hz}, \mathrm{OH}), 3.35$ $(1 \mathrm{H}, \mathrm{d}, J=5 \mathrm{~Hz}, \mathrm{OH}), 4.04\left(3 \mathrm{H}, \mathrm{m}, \mathrm{H}_{4}\right), 4.43(1 \mathrm{H}$, ddd, $\left.J_{2-3}=10 \mathrm{~Hz}, J_{2-1}=4 \mathrm{~Hz}, J_{2-1^{\prime}}=4 \mathrm{~Hz}, \mathrm{H}_{2}\right), 6.20(1 \mathrm{H}, \mathrm{d}$, $\left.J_{3^{\prime}-4^{\prime}}=9.6 \mathrm{~Hz}, \mathrm{H}_{3^{\prime}}\right), 6.56\left(1 \mathrm{H}, \mathrm{d}, J=3 \mathrm{~Hz}, \mathrm{H}_{1}\right), 6.74(1 \mathrm{H}, \mathrm{s}$, $\left.\mathrm{H}_{8^{\prime}}\right), 6.77\left(1 \mathrm{H}, \mathrm{d}, J_{6^{\prime}-5^{\prime}}=8.4 \mathrm{~Hz}, \mathrm{H}_{6^{\prime}}\right), 7.11(4 \mathrm{H}, \mathrm{m}), 7.19$ $(2 \mathrm{H}, \mathrm{m}), 7.33\left(1 \mathrm{H}, \mathrm{d}, J_{5^{\prime}-6^{\prime}}=8.4 \mathrm{~Hz}, \mathrm{H}_{5^{\prime}}\right), 7.35(4 \mathrm{H}, \mathrm{m})$, $7.54\left(1 \mathrm{H}, \mathrm{d}, J_{4^{\prime}-3^{\prime}}=9.6 \mathrm{~Hz}, \mathrm{H}_{4^{\prime}}\right) .{ }^{13} \mathrm{C}$ NMR $(100 \mathrm{MHz}$, $\left.\mathrm{CD}_{3} \mathrm{COCD}_{3}\right) \delta: 70.6\left(\mathrm{C}_{4}\right), 72.4\left(\mathrm{C}_{2}\right), 72.9\left(\mathrm{C}_{3}\right), 102.3\left(\mathrm{C}_{6^{\prime}}\right)$, $113.5\left(\mathrm{C}_{8^{\prime}}\right), 113.7\left(\mathrm{C}_{3^{\prime}}\right), 123.1\left(\mathrm{C}_{2^{\prime \prime}}\right), 125.2\left(\mathrm{C}_{4^{\prime}}\right), 130.1$ $\left(\mathrm{C}_{5^{\prime}}\right), 130.6\left(\mathrm{C}_{3^{\prime \prime}}\right), 138.9\left(\mathrm{C}_{1}\right), 144.5\left(\mathrm{C}_{4^{\prime}}\right), 144.7\left(\mathrm{C}_{1^{\prime \prime}}\right)$.

4.1.9. 4-O-Acetyl-2,3-O-isopropylidene-5-O-terbutyldimethylsilyl-1-O-tosyl-D-ribitol (15b). In $16 \mathrm{~mL}$ of anhydrous dichloromethane were dissolved $400 \mathrm{mg}$ $(1.3 \mathrm{mmol})$ of compound $\mathbf{1 4}, 273 \mathrm{mg}(1.43 \mathrm{mmol}$, 1.1 equiv) of tosyl chloride, $192 \mu \mathrm{L} \quad(1.43 \mathrm{mmol}$, 1.1 equiv) of anhydrous triethylamine and $160 \mathrm{mg}$ (1.3 mmol, 1 equiv) of DMAP. The reaction mixture was stirred for $30 \mathrm{~min}$ at room temperature and was monitored by TLC using cyclohexane/ethyl acetate $7: 3$ as eluent. $615 \mathrm{mg}$ ( $6.5 \mathrm{mmol}, 5$ equiv) of acetic anhydride was then added followed by $364 \mu \mathrm{L}(2.8 \mathrm{mmol}, 2.2$ equiv) of anhydrous triethylamine. The mixture was evaporated under vacuum. The crude product was dissolved in ethyl acetate and the organic phase was washed three times with water. After drying on $\mathrm{MgSO}_{4}$, rotary evaporation and flash chromatography on silica gel (cyclohexane/ethyl acetate $8: 2), 346 \mathrm{mg}(53 \%)$ of product $\mathbf{1 5 b}$ was obtained as a colourless oil.

TLC: $R_{\mathrm{f}}$ (cyclohexane/AcOEt $7: 3$ ) $=0.65 .{ }^{1} \mathrm{H}$ NMR $\left(400 \mathrm{MHz}, \mathrm{CDCl}_{3}\right) \delta: 0.02\left(6 \mathrm{H}, \mathrm{s}, 2 \mathrm{H}_{8}\right), 0.87(9 \mathrm{H}, \mathrm{s}$, $\left.9 \mathrm{H}_{10}\right), 1.30-1.31\left(6 \mathrm{H}, 2 \mathrm{~s}, 2 \mathrm{H}_{7}\right), 2.04\left(3 \mathrm{H}, \mathrm{s}, \mathrm{H}_{17}\right), 2.44(3 \mathrm{H}$, $\left.\mathrm{s}, \mathrm{H}_{15}\right), 3.74\left(1 \mathrm{H}, \mathrm{dd}, J_{5-4}=4 \mathrm{~Hz}, J_{5-5^{\prime}}=12 \mathrm{~Hz}, \mathrm{H}_{5}\right), 3.87$ $\left(1 \mathrm{H}, \mathrm{dd}, J_{5^{\prime}-4}=2 \mathrm{~Hz}, J_{5^{\prime}-5}=12 \mathrm{~Hz}, \mathrm{H}_{5^{\prime}}\right), 3.92(1 \mathrm{H}$, dd, $\left.J_{1-2}=7 \mathrm{~Hz}, J_{1-1^{\prime}}=10 \mathrm{~Hz}, \mathrm{H}_{1}\right), 4.08\left(1 \mathrm{H}, \mathrm{dd}, J_{1^{\prime}-2}=6 \mathrm{~Hz}\right.$, $\left.J_{1^{\prime}-1}=10 \mathrm{~Hz}, \mathrm{H}_{1}\right), 4.38\left(2 \mathrm{H}, \mathrm{m}, \mathrm{H}_{2}+\mathrm{H}_{3}\right), 4.78(1 \mathrm{H}$, ddd, $\left.J_{4-5^{\prime}}=2 \mathrm{~Hz}, J_{4-5}=4 \mathrm{~Hz}, J_{4-3}=9 \mathrm{~Hz}, \mathrm{H}_{4}\right), 7.33(2 \mathrm{H}, \mathrm{d}$, $\left.J_{13-12}=8 \mathrm{~Hz}, 2 \mathrm{H}_{13}\right), 7.80\left(2 \mathrm{H}, \mathrm{d}, J_{12-13}=8 \mathrm{~Hz}, 2 \mathrm{H}_{12}\right) \cdot{ }^{13} \mathrm{C}$ NMR $\left(100 \mathrm{MHz}, \mathrm{CDCl}_{3}\right) \delta:-5.4\left(2 \mathrm{C}_{8}\right), 18.4\left(\mathrm{C}_{9}\right), 21.1$, 
$21.8\left(2 \mathrm{C}_{7}\right), 25.9\left(3 \mathrm{C}_{10}\right), 27.0\left(\mathrm{C}_{15}\right), 27.9\left(\mathrm{C}_{17}\right), 62.0\left(\mathrm{C}_{5}\right)$, $68.2\left(\mathrm{C}_{1}\right), 71.6\left(\mathrm{C}_{4}\right), 73.8\left(\mathrm{C}_{3}\right), 75.0\left(\mathrm{C}_{2}\right), 109.3\left(\mathrm{C}_{6}\right), 128.2$, $130.0\left(\mathrm{C}_{12}+\mathrm{C}_{13}\right), 132.8\left(\mathrm{C}_{14}\right), 145.0\left(\mathrm{C}_{11}\right), 170.0\left(\mathrm{C}_{16}\right)$. HRMS $\left(\mathrm{ESI}^{+}\right) \mathrm{m} / \mathrm{z}:\left[\mathrm{M}+\mathrm{H}^{+}\right]$: calculated for $\mathrm{C}_{23} \mathrm{H}_{39} \mathrm{O}_{8} \mathrm{SiS}$ 503.2135, found 503.2141.

4.1.10. 4-O-Acetyl-2,3-O-isopropylidene-1-O-(2'-oxobenzopyran- $7^{\prime}-\mathrm{yl}$ )-5-O-terbutyldimethylsilyl-D (16). The tetrabutylammonium salt of umbelliferone was obtained by mixing $616 \mathrm{mg} \mathrm{(} 3.8 \mathrm{mmol}, 1$ equiv) of umbelliferone with

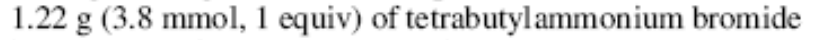
in $10 \mathrm{~mL}$ of a $\mathrm{NaOH}$ solution $(228 \mathrm{mg}, 5.7 \mathrm{mmol}$, 1.5 equiv). After stirring for few minutes, the salt was extracted with chloroform and the organic phase was dried on $\mathrm{MgSO}_{4}$ and evaporated under vacuum. Thus $1.5 \mathrm{~g}$ of crude salt was obtained and used without further purification. The salt previously obtained was transferred to a flask containing $200 \mathrm{mg}$ of $\mathbf{1 5 b}(0.38 \mathrm{mmol}, 1$ equiv) dissolved in $20 \mathrm{~mL}$ of anhydrous DMF. The mixture was then stirred for $96 \mathrm{~h}$ at $50^{\circ} \mathrm{C}$ under argon. The reaction was monitored by TLC using cyclohexane/ethyl acetate $6: 4$ as eluent. After disappearance of the starting compound, $50 \mathrm{~mL}$ of water was added followed by $50 \mathrm{~mL}$ of ethyl acetate, and the aqueous phase was extracted twice with $2 \times 50 \mathrm{~mL}$ of ethyl acetate. The organic phase was dried on $\mathrm{MgSO}_{4}$ and evaporated under vacuum. The crude product was purified by column chromatography on silica gel using cyclohexane/ethyl acetate 6:4 as eluent. Compound $\mathbf{1 6}$ was isolated in $60 \%$ yield as a white solid.

TLC: $R_{\mathrm{f}}$ (cyclohexane/AcOEt 6:4) $=0.42 . \mathrm{Mp} 95-96{ }^{\circ} \mathrm{C} .{ }^{1} \mathrm{H}$ NMR $\left(400 \mathrm{MHz}, \mathrm{CDCl}_{3}\right) \delta: 0.03\left(6 \mathrm{H}, \mathrm{s}, 2 \mathrm{H}_{8}\right), 0.87(9 \mathrm{H}, \mathrm{s}$, $\left.3 \mathrm{H}_{10}\right), 1.39,1.47\left(6 \mathrm{H}, 2 \mathrm{~s}, 2 \mathrm{H}_{7}\right), 2.03\left(3 \mathrm{H}, \mathrm{s}, \mathrm{H}_{12}\right), 3.81$ $\left(1 \mathrm{H}, \mathrm{dd}, J_{5 \mathrm{a}-4}=4 \mathrm{~Hz}, J_{5 \mathrm{a}-5 \mathrm{~b}}=12 \mathrm{~Hz}, \mathrm{H}_{5 \mathrm{a}}\right), 3.92(1 \mathrm{H}$, dd, $\left.J_{5 \mathrm{~b}-4}=2 \mathrm{~Hz}, J_{5 \mathrm{~b}-5 \mathrm{a}}=12 \mathrm{~Hz}, \mathrm{H}_{5 \mathrm{~b}}\right), 4.09\left(1 \mathrm{H}, \mathrm{dd}, J_{1 \mathrm{a}-2}=\right.$ $\left.6 \mathrm{~Hz}, J_{1 \mathrm{a}-1 \mathrm{~b}}=10 \mathrm{~Hz}, \mathrm{H}_{1 \mathrm{a}}\right), 4.15\left(1 \mathrm{H}, \mathrm{dd}, J_{1 \mathrm{~b}-2}=5 \mathrm{~Hz}\right.$, $\left.J_{1 \mathrm{~b}-1 \mathrm{a}}=10 \mathrm{~Hz}, \mathrm{H}_{1 \mathrm{~b}}\right), 4.48\left(1 \mathrm{H}, \mathrm{dd}, J_{3-2}=6 \mathrm{~Hz}, J_{3-4}=\right.$ $\left.8 \mathrm{~Hz}, \mathrm{H}_{3}\right), 4.56\left(1 \mathrm{H}, \mathrm{m}, \mathrm{H}_{2}\right), 5.02\left(1 \mathrm{H}\right.$, ddd, $J_{4-5 \mathrm{~b}}=2 \mathrm{~Hz}$, $\left.J_{4-5 \mathrm{a}}=4 \mathrm{~Hz}, J_{4-3}=8 \mathrm{~Hz}, \mathrm{H}_{4}\right), 6.24\left(1 \mathrm{H}, \mathrm{d}, J_{3^{\prime}-4^{\prime}}=10 \mathrm{~Hz}\right.$, $\left.\mathrm{H}_{3^{\prime}}\right), 6.78\left(1 \mathrm{H}, \mathrm{s}, \mathrm{H}_{8^{\prime}}\right), 6.82\left(1 \mathrm{H}, \mathrm{d}, J_{6^{\prime}-5^{\prime}}=9 \mathrm{~Hz}, \mathrm{H}_{6^{\prime}}\right), 7.36$ $\left(1 \mathrm{H}, \mathrm{d}, J_{5^{\prime}-6^{\prime}}=9 \mathrm{~Hz}, \mathrm{H}_{5^{\prime}}\right), 7.62\left(1 \mathrm{H}, \mathrm{d}, J_{4^{\prime}-3^{\prime}}=10 \mathrm{~Hz}, \mathrm{H}_{4^{\prime}}\right)$. ${ }^{13} \mathrm{C}$ NMR $\left(100 \mathrm{MHz}, \mathrm{CDCl}_{3}\right) \delta:-5.4\left(2 \mathrm{C}_{8}\right), 18.4\left(\mathrm{C}_{9}\right), 21.3$ $\left(\mathrm{C}_{12}\right), 25.5\left(2 \mathrm{C}_{7}\right), 25.9\left(3 \mathrm{C}_{10}\right), 62.3\left(\mathrm{C}_{5}\right), 67.3\left(\mathrm{C}_{1}\right), 72.0$ $\left(\mathrm{C}_{2}\right), 74.2\left(\mathrm{C}_{4}\right), 75.4\left(\mathrm{C}_{3}\right), 101.8\left(\mathrm{C}_{6^{\prime}}\right), 109.2\left(\mathrm{C}_{6}\right), 112.8$ $\left(\mathrm{C}_{8^{\prime}}\right), 113.0\left(\mathrm{C}_{9^{\prime}}\right), 113.5\left(\mathrm{C}_{3^{\prime}}\right), 129.0\left(\mathrm{C}_{5^{\prime}}\right), 143.4\left(\mathrm{C}_{4^{\prime}}\right), 155.9$ $\left(\mathrm{C}_{10^{\prime}}\right), 161.2\left(\mathrm{C}_{7^{\prime}}\right), 161.8\left(\mathrm{C}_{2^{\prime}}\right), 170.0\left(\mathrm{C}_{11}\right)$. HRMS $\left(\mathrm{ESI}^{+}\right)$ $m / z:\left[\mathrm{M}+\mathrm{H}^{+}\right]$: calculated for $\mathrm{C}_{25} \mathrm{H}_{37} \mathrm{O}_{8} \mathrm{Si} 493.2258$, found 493.2267.

4.1.11. 2,3-O-Isopropylidene-1-O-(2'-oxo-benzopyran$7^{\prime}$-yl)-5-O-terbutyl-dimethylsilyl-d (17). To a solution of $191 \mathrm{mg}(0.39 \mathrm{mmol})$ of compound $16 \mathrm{in} 9 \mathrm{~mL}$ of methanol were added $107 \mathrm{mg}(0.77 \mathrm{mmol}, 2$ equiv) of potassium carbonate. The mixture was stirred at room temperature for $4 \mathrm{~h}$. After disappearance of the starting compound (cyclohexane/ethyl acetate 4:6), a mixture of ethyl acetate and water (v/v 1:1) was added and the solution was extracted. The organic phase was dried under $\mathrm{MgSO}_{4}$ and evaporated under vacuum to give $141 \mathrm{mg}(90 \%)$ of compound $\mathbf{1 7}$ as a colourless oil, used without further purification.

TLC: $R_{\mathrm{f}}$ (cyclohexane/AcOEt $\left.4: 6\right)=0.65 .[\alpha]_{\mathrm{D}}^{24}-22.75(c$ $\left.0.4, \mathrm{CHCl}_{3}\right) .{ }^{1} \mathrm{H}$ NMR $\left(400 \mathrm{MHz}, \mathrm{CDCl}_{3}\right) \delta: 0.102(6 \mathrm{H}, \mathrm{s}$, $\left.2 \mathrm{H}_{8}\right), 0.92\left(9 \mathrm{H}, \mathrm{s}, 3 \mathrm{H}_{10}\right), 1.39,1.47\left(6 \mathrm{H}, 2 \mathrm{~s}, 2 \mathrm{H}_{7}\right), 3.70(2 \mathrm{H}$, $\left.\mathrm{m}, \mathrm{H}_{4}+\mathrm{H}_{5 \mathrm{a}}\right), 3.85\left(1 \mathrm{H}, \mathrm{dd}, J_{5 \mathrm{~b}-4}=5 \mathrm{~Hz}, J_{5 \mathrm{~b}-5 \mathrm{a}}=12 \mathrm{~Hz}\right.$, $\left.\mathrm{H}_{5 \mathrm{~b}}\right), 4.12\left(1 \mathrm{H}, \mathrm{dd}, J_{1 \mathrm{a}-2}=6 \mathrm{~Hz}, J_{1 \mathrm{a}-1 \mathrm{~b}}=10 \mathrm{~Hz}, \mathrm{H}_{1 \mathrm{a}}\right), 4.19$ $\left(1 \mathrm{H}, \mathrm{dd}, J_{1 \mathrm{~b}-2}=8 \mathrm{~Hz}, J_{1 \mathrm{~b}-1 \mathrm{a}}=10 \mathrm{~Hz}, \mathrm{H}_{1^{\prime}}\right), 4.48(1 \mathrm{H}, \mathrm{dd}$, $\left.J_{3-2}=3 \mathrm{~Hz}, J_{3-4}=10 \mathrm{~Hz}, \mathrm{H}_{3}\right), 4.60\left(1 \mathrm{H}\right.$, ddd, $J_{2-3}=3 \mathrm{~Hz}$, $\left.J_{2-1 \mathrm{a}}=6 \mathrm{~Hz}, J_{2-1 \mathrm{~b}}=8 \mathrm{~Hz}, \mathrm{H}_{2}\right), 6.25\left(1 \mathrm{H}, \mathrm{d}, J_{3^{\prime}-4^{\prime}}=9 \mathrm{~Hz}\right.$, $\left.\mathrm{H}_{3^{\prime}}\right), 6.89\left(1 \mathrm{H}, \mathrm{s}, \mathrm{H}_{8^{\prime}}\right), 6.92\left(1 \mathrm{H}, \mathrm{d}, J_{6^{\prime}-5^{\prime}}=8 \mathrm{~Hz}, \mathrm{H}_{6^{\prime}}\right), 7.36$ $\left(1 \mathrm{H}, \mathrm{d}, J_{5^{\prime}-6^{\prime}}=8 \mathrm{~Hz}, \mathrm{H}_{5^{\prime}}\right), 7.63\left(1 \mathrm{H}, \mathrm{d}, J_{4^{\prime}-3^{\prime}}=9 \mathrm{~Hz}, \mathrm{H}_{4^{\prime}}\right)$. ${ }^{13} \mathrm{C}$ NMR (100 MHz, CDCl 3 ) $\delta:-5.2\left(2 \mathrm{C}_{8}\right), 18.5\left(\mathrm{C}_{9}\right), 25.7$ $\left(2 \mathrm{C}_{7}\right), 26.0\left(3 \mathrm{C}_{10}\right), 64.4\left(\mathrm{C}_{1}\right), 68.1\left(\mathrm{C}_{5}\right), 69.5\left(\mathrm{C}_{4}\right), 76.1\left(\mathrm{C}_{2}+\right.$ $\left.\mathrm{C}_{3}\right), 101.9\left(\mathrm{C}_{6}\right), 109.6\left(\mathrm{C}_{6}\right), 112.7\left(\mathrm{C}_{8^{\prime}}\right), 112.8\left(\mathrm{C}_{9^{\prime}}\right), 113.3$ $\left(\mathrm{C}_{3^{\prime}}\right), 128.8\left(\mathrm{C}_{5^{\prime}}\right), 143.5\left(\mathrm{C}_{4^{\prime}}\right), 155.8\left(\mathrm{C}_{1} \mathrm{C}^{\prime}\right), 161.3\left(\mathrm{C}_{7^{\prime}}\right), 162.2$ $\left(\mathrm{C}_{2^{\prime}}\right)$. MS $m / z 473\left(\mathrm{M}+\mathrm{Na}^{+}\right)$. HRMS $m / z:\left[\mathrm{M}+\mathrm{Na}^{+}\right]$: calculated for $\mathrm{C}_{23} \mathrm{H}_{34} \mathrm{NaO}_{7} \mathrm{Si} 473.1971$, found 473.1965 .

4.1.12. 2,3-O-Isopropylidene-4-oxo-5-O-terbutyldimethylsilyl-7'-(2,3,5-trihydroxy-4-oxo-pentyl)oxycoumarine (18). Four hundred and ten milligrams ( $0.96 \mathrm{mmol}, 1.4$ equiv) of Dess-Martin reagent were dissolved in $6 \mathrm{~mL}$ of anhydrous dichloromethane. $310 \mathrm{mg}$ ( $0.69 \mathrm{mmol}, 1$ equiv) of compound 17 dissolved in $4 \mathrm{~mL}$ of anhydrous dichloromethane were then added and the mixture was stirred for $5 \mathrm{~h}$ at room temperature. $30 \mathrm{~mL}$ of diethyl ether were poured in followed by $12 \mathrm{~mL}$ of a $1.3 \mathrm{M}$ $\mathrm{NaOH}$ solution. The mixture was stirred for $10 \mathrm{~min}$ and the organic layer was washed with $20 \mathrm{~mL}$ of water, dried on $\mathrm{MgSO}_{4}$ and evaporated under reduced pressure to yield $230 \mathrm{mg}(74 \%)$ of yellow oil, used in the next step without further purification.

TLC: $R_{\mathrm{f}}$ (cyclohexane/AcOEt $\left.4: 6\right)=0.69 .[\alpha]_{\mathrm{D}}^{24}-52.2$ (c $\left.1, \mathrm{CHCl}_{3}\right) .{ }^{1} \mathrm{H}$ NMR $\left(400 \mathrm{MHz}, \mathrm{CDCl}_{3}\right) \delta: 0.06(9 \mathrm{H}, \mathrm{s}$, $\left.2 \mathrm{H}_{8}\right), 0.88\left(9 \mathrm{H}, \mathrm{s}, 3 \mathrm{H}_{10}\right), 1.40,1.58\left(6 \mathrm{H}, 2 \mathrm{~s}, 2 \mathrm{H}_{7}\right), 4.00(1 \mathrm{H}$, dd, $\left.J_{1-2}=4 \mathrm{~Hz}, J_{1-1^{\prime}}=10 \mathrm{~Hz}, \mathrm{H}_{1}\right), 4.15\left(1 \mathrm{H}, \mathrm{dd}, J_{1^{\prime}-2}=\right.$ $\left.4 \mathrm{~Hz}, J_{1^{\prime}-1}=10 \mathrm{~Hz}, \mathrm{H}_{1^{\prime}}\right), 4.52\left(2 \mathrm{H}, 2 \mathrm{~s}, J_{5 \mathrm{a}-5 \mathrm{~b}}=19 \mathrm{~Hz}, 2 \mathrm{H}_{5}\right)$, $4.77\left(1 \mathrm{H}\right.$, ddd, $\left.J_{2-1}=4 \mathrm{~Hz}, J_{2-1^{\prime}}=4 \mathrm{~Hz}, J_{2-3}=8 \mathrm{~Hz}, \mathrm{H}_{2}\right)$, $4.87\left(1 \mathrm{H}, \mathrm{d}, J_{3-2}=8 \mathrm{~Hz}, \mathrm{H}_{3}\right), 6.24\left(1 \mathrm{H}, \mathrm{d}, J_{3^{\prime}-4^{\prime}}=9 \mathrm{~Hz}, \mathrm{H}_{3^{\prime}}\right)$, $6.77\left(1 \mathrm{H}, \mathrm{s}, \mathrm{H}_{8^{\prime}}\right), 6.79\left(1 \mathrm{H}, \mathrm{d}, J_{6^{\prime}-5^{\prime}}=8 \mathrm{~Hz}, \mathrm{H}_{6^{\prime}}\right), 7.33(1 \mathrm{H}, \mathrm{d}$, $\left.J_{5^{\prime}-6^{\prime}}=8 \mathrm{~Hz}, \mathrm{H}_{5^{\prime}}\right), 7.61\left(1 \mathrm{H}, \mathrm{d}, J_{4^{\prime}-3^{\prime}}=9 \mathrm{~Hz}, \mathrm{H}_{4^{\prime}}\right) .{ }^{13} \mathrm{C} \mathrm{NMR}$ $\left(100 \mathrm{MHz}, \mathrm{CDCl}_{3}\right) \delta:-5.3\left(2 \mathrm{C}_{8}\right), 18.4\left(\mathrm{C}_{9}\right), 24.9\left(2 \mathrm{C}_{7}\right)$, $26.0\left(3 \mathrm{C}_{10}\right), 66.5\left(\mathrm{C}_{1}\right), 68.5\left(\mathrm{C}_{5}\right), 76.0\left(\mathrm{C}_{2}\right), 76.5\left(\mathrm{C}_{3}\right), 102.2$ $\left(\mathrm{C}_{6^{\prime}}\right), 110.5\left(\mathrm{C}_{6}\right), 112.7\left(\mathrm{C}_{8^{\prime}}\right), 113.2\left(\mathrm{C}_{9^{\prime}}\right), 113.6\left(\mathrm{C}_{3^{\prime}}\right), 128.9$ $\left(\mathrm{C}_{5^{\prime}}\right), 143.3\left(\mathrm{C}_{4^{\prime}}\right), 154.8\left(\mathrm{C}_{10^{\prime}}\right), 161.2\left(\mathrm{C}_{2^{\prime}}+\mathrm{C}_{7^{\prime}}\right), 206.5\left(\mathrm{C}_{4}\right)$. HRMS $m / z\left[\mathrm{M}+\mathrm{H}^{+}\right]$: calculated for $\mathrm{C}_{23} \mathrm{H}_{33} \mathrm{O}_{7} \mathrm{Si} 449.1996$, found 449.2002 .

4.1.13. $7^{\prime}$-(2,3,5-Trihydroxy-4-oxo-pentyl)oxycoumarine (3). Eighty six milligrams $(0.19 \mathrm{mmol})$ of compound 18 and $48 \mathrm{mg}$ ( $0.19 \mathrm{mmol}, 1$ equiv) of iodine were dissolved in $8 \mathrm{~mL}$ of methanol. The mixture was stirred and refluxed for $2 \mathrm{~h}$. After disappearance of the starting compound (dichloromethane/methanol 9:1), the reaction mixture was cooled in an ice bath and $30 \mathrm{mg}$ ( $1.9 \mathrm{mmol}, 10$ equiv) of $\mathrm{Na}_{2} \mathrm{SO}_{3}$ was added under stirring. After evaporation of methanol under vacuum and flash chromatography on silica gel (dichloromethane/methanol 95:5), $32 \mathrm{mg}$ of the final compound 3 was obtained $(56 \%)$ as a colourless oil.

TLC: $R_{\mathrm{f}}\left(\mathrm{CH}_{2} \mathrm{Cl}_{2} / \mathrm{MeOH} 9: 1\right)=0.62 .[\alpha]_{\mathrm{D}}^{24}-16.4(c 1$, $\mathrm{MeOH}) .{ }^{1} \mathrm{H}$ NMR $\left(400 \mathrm{MHz}, \mathrm{CD}_{3} \mathrm{COCD}_{3}\right) \delta: 4.12(1 \mathrm{H}$, dd, $\left.J_{1 \mathrm{a}-2}=6 \mathrm{~Hz}, J_{1 \mathrm{a}-1 \mathrm{~b}}=10 \mathrm{~Hz}, \mathrm{H}_{1 \mathrm{a}}\right), 4.21\left(2 \mathrm{H}, \mathrm{m}, \mathrm{H}_{1 \mathrm{~b}}+\mathrm{H}_{2}\right)$, $4.35\left(1 \mathrm{H}, \mathrm{d}, J_{3-2}=5 \mathrm{~Hz}, \mathrm{H}_{3}\right), 4.52\left(2 \mathrm{H}, 2 \mathrm{~d}, J_{5 \mathrm{a}-5 \mathrm{~b}}=19 \mathrm{~Hz}\right.$, $\left.2 \mathrm{H}_{5}\right), 5.37\left(1 \mathrm{H}, \mathrm{d}, J_{3^{\prime}-4^{\prime}}=10 \mathrm{~Hz}, \mathrm{H}^{\prime}\right), 6.05\left(1 \mathrm{H}, \mathrm{s}, \mathrm{H}_{8^{\prime}}\right)$, 
$6.07\left(1 \mathrm{H}, \mathrm{d}, J_{6^{\prime}-5^{\prime}}=8 \mathrm{~Hz}, \mathrm{H}_{6^{\prime}}\right), 6.66\left(1 \mathrm{H}, \mathrm{d}, J_{5^{\prime}-6^{\prime}}=8 \mathrm{~Hz}\right.$, $\left.\mathrm{H}_{5^{\prime}}\right), 7.00\left(1 \mathrm{H}, \mathrm{d}, J_{4^{\prime}-3^{\prime}}=10 \mathrm{~Hz}, \mathrm{H}_{4^{\prime}}\right) .{ }^{13} \mathrm{C}$ NMR $(100 \mathrm{MHz}$, $\left.\mathrm{CDCl}_{3}\right) \delta: 67.9\left(\mathrm{C}_{5}\right), 69.7\left(\mathrm{C}_{1}\right), 72.3\left(\mathrm{C}_{2}\right), 77.2\left(\mathrm{C}_{3}\right), 102.5$ $\left(\mathrm{C}_{6^{\prime}}\right), 113.4\left(\mathrm{C}_{8^{\prime}}\right), 113.6\left(\mathrm{C}_{9^{\prime}}\right), 114.0\left(\mathrm{C}_{3^{\prime}}\right), 130.5\left(\mathrm{C}_{5^{\prime}}\right), 145.7$ $\left(\mathrm{C}_{4^{\prime}}\right), 156.8\left(\mathrm{C}_{10^{\prime}}\right), 161.1\left(\mathrm{C}_{7^{\prime}}\right), 162.8\left(\mathrm{C}_{2^{\prime}}\right), 212.4\left(\mathrm{C}_{4}\right)$. HRMS $m / z:\left[\mathrm{M}+\mathrm{Na}^{+}\right]$: calculated for $\mathrm{C}_{14} \mathrm{H}_{14} \mathrm{NaO}_{7}$ 317.0637 , found 317.0627 .

\subsection{Yeast TK fluorogenic assays}

TK enzyme $\left(0-0.02 \mathrm{mg} \mathrm{mL}^{-1}\right)$ was incubated for $30 \mathrm{~min}$ in a reaction mixture containing $2 \mathrm{mM} \mathrm{ThDP}, 3 \mathrm{mM} \mathrm{MgCl}$, $1 \mathrm{mM}$ D-ribose-5-phosphate, $100 \mu \mathrm{M}$ of fluorogenic substrate $\left(1,2\right.$ or 3 ) and $2 \mathrm{mg} \mathrm{mL}^{-1}$ BSA in a $50 \mathrm{mM}$ aq Tris buffer, $\mathrm{pH}$ 8.2. The reaction progress was followed by fluorescence detection at $\lambda_{\mathrm{em}}=412 \mathrm{~nm}\left(\lambda_{\mathrm{ex}}=390 \mathrm{~nm}\right)$. Fluorescence was correlated with umbelliferone concentration by means of a calibration curve.

\section{Acknowledgements}

This work was supported by MENRT ( $\mathrm{PhD}$ grant and postdoctoral fellowship).

\section{References and notes}

1. (a) Jaeger, K. E.; Reetz, M. T. Curr. Opin. Chem. Biol. 2000, 4, 68-73. (b) Beisson, F.; Tiss, A.; Riviere, C.; Verger, R. Eur. J. Lipid Sci. Technol. 2000, 133-153.

2. (a) MacBeath, G.; Hilvert, D. J. Am. Chem. Soc. 1994, 116, 6101-6106. (b) Tawfik, D. S.; Green, B. S.; Chap, R.; Sela, M.; Eshhar, Z. Proc. Natl. Acad. Sci. USA 1993, 90, 373-377.

3. (a) Taylor, S. J.; Morken, J. P. Science 1998, 280, 267-270. (b) Holzwarth, A.; Schmidt, H. W.; Maier, W. F. Angew. Chem. Int. Ed. 1998, 37, 2644-2647.

4. (a) Reetz, M. T.; Becker, M. H.; Klein, H. W.; Stockigt, D. Angew. Chem., Int. Ed. 1999, 38, 1758-1761. (b) Reetz, M. T. Angew. Chem., Int. Ed. 2001, 40, 284-310.

5. Goddard, J. P.; Reymond, J. L. Trends Biotechnol. 2004, 22, $363-370$.

6. (a) Klein, G.; Reymond, J. L. Bioorg. Med. Chem. Lett. 1998, 8,1113-1116. (b) Klein, G.; Reymond, J. L. Helv. Chim. Acta 1999, $82,400-407$.

7. (a) Badalassi, F.; Wahler, D.; Klein, G.; Crotti, P.; Reymond, J. L. Angew. Chem., Int. Ed. 2000, 39, 4067-4070. (b) Wahler, D.; Badalassi, F.; Crotti, P.; Reymond, J. L. Angew.Chem., Int. Ed. 2001, 40, 4457-4460. (c) Wahler, D.; Badalassi, F.; Crotti, P.; Reymond, J. L. Chem. Eur. J. 2002, 8, 3211-3228.

8. Perez-Carlon, R.; Jourdain, N.; Reymond, J. L. Chem. Eur. J. 2000, 6, 4154-4162.

9. Gonzalez-Garcia, E.; Hélaine, V.; Klein, G.; Schuermann, M.; Sprenger, G. A.; Fessner, W. D.; Reymond, J. L. Chem. Eur. J. 2003, 9, 893-899.

10. Bolte, J.; Demuynck, C.; Hecquet, L.; Samaki, H. Carbohydr. Res. 1990, 206, 79-85.

11. (a) Ziegler, T.; Straub, A.; Effenberger, F. Angew. Chem., Int. Ed. Engl. 1988, 27, 716-721. (b) Kobori, Y.; Myles, D. C.; Withesides, G. M. J. Org. Chem. 1991, 22, 5899-5907. (c) Morris, K. G.; Smith, M. E. B.; Turner, N. J. Tetrahedron:
Asymmetry 1996, 7, 2185-2188. (d) Zimmermann, F. T.; Schneider, A.; Schörken, Y.; Sprenger, G. A.; Fessner, W. D. Tetrahedron: Asymmetry 1999, 10, 1643-1646.

12. (a) Wikner, C.; Meshalkina, L.; Nilsson, U.; Nikkola, M.; Lindqvist, Y.; Schneider, G. J. Biol. Chem. 1994, 269, 32144-32150. (b) Nilsson, U.; Hecquet, L.; Gefflaut, T.; Guérard, C.; Schneider, G. FEBS Lett. 1998, 424, 49-52.

13. (a) André, C.; Guérard, C.; Hecquet, L.; Demuynck, C.; Bolte, J. J. Mol. Catal. B: Enzym. 1998, 5, 459-466. (b) Guérard, C.; Alphand, V.; Archelas, A.; Demuynck, C.; Hecquet, L; Furstoss, R.; Bolte, J. Eur. J. Org. Chem. 1999, 1, 3399-3402. (c) Crestia, D.; Guérard, C.; Veschambre, H.; Hecquet, L.; Demuynck, C.; Bolte, J. Tetrahedron: Asymmetry 2001, 12, 869-876.

14. Sevestre, A.; Hélaine, V.; Guyot, G.; Martin, C.; Hecquet, L. Tetrahedron Lett. 2003, 44, 827-830.

15. Clarke, D. J.; Robinson, R. S. Tetrahedron 2002, 58, 2831-2838.

16. Smith, A. B.; Jerris, P. J. Tetrahedron Lett. 1980, 21, 711-714.

17. (a) Machajewski, T. D.; Wong, C. H. Angew. Chem., Int. Ed. 2000, 39, 1352-1375. (b) Kobori, Y.; Myles, D. C.; Whitesides, G. M. J. Org. Chem. 1992, 57, 5899-5907. (c) Wymer, N.; Toone, E. J. Curr. Opin. Chem. Biol. 2000, 4, 110-119. (d) Wong, C. H.; Whitesides, G. M. J. Org. Chem. 1983, 48, 3199-3205. (e) Effenberger, F.; Null, V. Liebigs Ann. Chem. 1992, 1211-1212. (f) Ziegler, T.; Straub, A.; Effenberger, F. Angew. Chem., Int. Ed. Engl. 1988, 27, 716-717. (g) Bolte, J.; Demuynck, C.; Samaki, H. Tetrahedron Lett. 1987, 28, 5525-5528.

18. Charmantray, F.; El Blidi, L.; Gefflaut, T.; Hecquet, L.; Bolte, J.; Lemaire, M. J. Org. Chem. 2004, 69,9310-9312.

19. (a) Musich, J. A.; Rapoport, H. J. Am. Chem. Soc. 1978, 100, 4865-4872. (b) Batsanov, A. S.; Begley, M. J.; Fletcher, J. A.; Murphy, J. A. J. Chem. Soc., Perkin Trans. I 1995, 1281-1294.

20. Valverde, S.; Herradon, B.; Rabanal, R. M.; Martin-Lomas, M. Can. J. Chem. 1987, 65, 332.

21. Baumberger, F.; Vasella, A.; Schauer, R. Helv. Chim. Acta 1986, 69, 1927-1935.

22. Friestad, K. G.; Massari, E. S. J. Org. Chem. 2004, 69, $863-875$.

23. Kaskar, B.; Haise, G. L.; Michalak, R. S.; Vishnuvajjala, B. R. Synthesis 1990, 11, 1031-1032.

24. Sivets, G. G.; Klennitskaya, T. V.; Zhernosek, E. V.; Mikhailopulo, I. A. Synthesis 2002, 2, 253-259.

25. Clauss, R.; Hunter, R. J. Chem. Soc., Perkin Trans. 1 1997, $71-76$.

26. Kane, P. D.; Mann, J. J. Chem. Soc., Perkin Trans. I 1984, $657-660$.

27. Kim, D. K.; Kim, G.; Kim, Y. W. J. Chem. Soc., Perkin Trans. 1 1996, 8, 803-808.

28. Valverde, S.; Herradon, B.; Rabanal, R. M.; Martin-Lomas, M. Can. J. Chem. 1987, 65, 332.

29. Paterson, I.; Norcross, R. D.; Ward, R. A.; Romea, P.; Lister, M. A. J. Am. Chem. Soc. 1994, 116, 11287-11314.

30. Taylor, S. L.; Lee, D. Y.; Martin, J. C. J. Org. Chem. 1983, 48, 4156-4158.

31. Szarek, W. A.; Zamojski, A.; Tiwari, K. N.; Ison, E. R. Tetrahedron Lett. 1986, 27, 3827-3830.

32. Hecquet, L.; Demuynck, C.; Bolte, J. J. Mol. Catal. B: Enzym. 2001, 6, 797-802. 